\title{
Poultry
}

\section{Influence of feeding whole maize, differing in endosperm hardness, on the performance, nutrient utilisation and digestive tract development of broiler starters}

\author{
Y. Singh ${ }^{12}$ and V. Ravindran ${ }^{1} *$ \\ ${ }^{1}$ School of Agriculture and Environmental Science, Massey University, Palmerston North 4442, New Zealand \\ ${ }^{2}$ Present address: Department of Livestock Production and Management, College of Veterinary Science, Guru Angad Dev Veterinary and Animal \\ Science University (GADVASU), Ludhiana, Punjab, India. 141004
}

\section{Summary}

Use of whole wheat, along with compounded feeds, for poultry feeding is a common practice in many parts of the world. However, studies investigating the use of other grains are limited. In the present study, the influence of including whole maize, with differing hardness, in broiler diets on the performance, nutrient utilisation and digestive tract development was examined. The experimental design was a $3 \times 2$ factorial arrangement of treatments, evaluating maize hardness (hard, semi-hard or soft) with diets based on ground maize or $115 \mathrm{~g} / \mathrm{kg}$ whole maize replacing ground maize. The three maize cultivars were ground in a hammer mill to pass through a $4 \mathrm{~mm}$ sieve and six diets were developed based on one of the three cultivars. Following mixing, all diets were cold pelleted through a $3 \mathrm{~mm}$ die. Each of the six diets was fed to six replicate cages (eight birds per cage) from day 1 to 21 post-hatch. Maize hardness and whole maize inclusion had no effect $(\mathrm{P}>0.05)$ on weight gain. Maize hardness influenced $(\mathrm{P}<0.05)$ feed intake and feed per gain, while these two parameters were unaffected $(\mathrm{P}>0.05)$ by the inclusion of whole maize. The apparent metabolisable energy (AME) was unaffected ( $>>0.05)$ by maize hardness and whole maize inclusion. Maize hardness increased the ileal digestibility of nitrogen $(\mathrm{P}<0.05)$ and starch $(\mathrm{P}=0.06)$. The relative weight of the gizzard was greater $(\mathrm{P}<0.05)$ in birds fed hard and semi-hard maize compared to soft maize, and was greater $(\mathrm{P}<0.05)$ when whole maize was included. These results indicated that $115 \mathrm{~g} / \mathrm{kg}$ of ground maize can be replaced by whole maize in broiler starter diets with no adverse effects on growth performance and thus can reduce the cost of feed manufacture.

Keywords: Whole maize: hardness: broilers: performance: nutrient: gut development

(Received 8 October 2018 - Accepted 19 November 2018)

\section{Introduction}

Feed represents the major cost of poultry production, constituting up to $70 \%$ of the total cost. Feeding whole grains to poultry has received much attention in recent years as an alternative management practice to reduce the feed cost, through savings in the cost of grinding, handling and processing of grains (Singh et al., 2015). This mode of feeding has not only shown positive effects on the performance but it also meets the consumer demands for a more 'natural' feeding system and improved animal welfare (Gabriel et al., 2007). It is well documented that the incorporation of whole grains results in increased size and weight of the gizzard (Singh et al., 2015, Liu et al., 2015). A more developed gizzard enhances the grinding of feed that will increase the exposure of nutrients to digestive enzymes and 
improve bird performance (Ravindran et al., 2006; Rodriques and Choct, 2018).

The literature pertaining to whole grain feeding primarily involves supplementation of whole wheat into diets, but studies investigating the use of other grains are limited. Published data on the effect of whole wheat feeding on the performance of broilers have been contradictory, with some reports showing beneficial effects (Wu et al., 2004; Ravindran et al., 2006), while others failing to show any advantage (Bennett et al., 2002; Amerah and Ravindran, 2008). Dietary factors such as type and hardness of cereals may contribute, in part, to the variable responses seen with whole grain feeding, but this aspect has received only limited attention (Amerah et al., 2009). The aim of the present study was to investigate the interaction between maize hardness and whole maize inclusion on the performance parameters of growing broiler chickens. The diets were pelleted after the inclusion of whole maize to take into the account of commercial practice in the use of whole cereals. The tested hypothesis was that whole or hard maize would require greater grinding activity in the gizzard, stimulating the size of this organ and its effect on performance, nutrient utilisation and digestive tract development in broiler starters.

\section{Materials and methods}

\section{Analysis of maize samples}

Three maize cultivars differing in hardness (34B97, C4187 and C8449) were obtained as whole grain from a commercial plant breeder. Upon receipt, requisite samples of maize were analysed to confirm the differences in hardness (Table 1). Maize hardness was determined using the Stenvert hardness test based on the method described by Stenvert (1974) and Pomeranz et al. (1985). Accordingly, C4187, 34B97 and C8449 cultivars of maize were classified as hard, semi-hard, and soft, respectively.

\section{Particle size of grains}

The particle size spectrum of each maize cultivar was characterised by dry sieving using the method described by Baker and Herrman (2002). In brief, whole grains were ground in a hammer mill to pass through a 4-mm sieve and two representative ground samples were obtained. Samples $(100 \mathrm{~g})$ were passed through a geometric series of sieves, and amount of sample retained on each sieve determined. The geometric mean diameter (GMD) and geometric standard deviation (GSD) were then determined.
Table 1. The results of Stenvert hardness test conducted on three cultivars of maize.

Maize cultivar $^{1}$ Milling energy ${ }^{2}(\mathrm{KJ})$

${ }^{1}$ Average of three measurements.

${ }^{2}$ Equates to the amount of energy required to mill a $20 \mathrm{~g}$ whole grain. Results were adjusted to $14 \%$ moisture content (Stenvert, 1974).

\section{Determination of particle size distribution in the diets}

The particle size spectra of final diet samples were determined by wet sieving using the method described by Lentle et al. (2006). Briefly, $50 \mathrm{~g}$ weighed samples were divided into two sub-samples of $25 \mathrm{~g}$ each. One subsample was oven-dried at $80^{\circ} \mathrm{C}$ in a forced draft oven for $24 \mathrm{~h}$ to determine the dry matter content, while the other sub-sample was suspended in $50 \mathrm{ml}$ of water and left to stand for $30 \mathrm{~min}$ before being washed though a series of sieves (Endocott, London, UK) sized 2, 1, $0.5,0.25,0.106$ and $0.075 \mathrm{~mm}$. Contents of each sieve were subsequently washed onto pre-weighed filter papers, and then dried for $24 \mathrm{~h}$ in a forced draft oven at $80^{\circ} \mathrm{C}$. Amount of diets retained by each sieve and fines, which passed through all sieves, were expressed as a percentage of the total dry matter recovered.

\section{Experimental design and diets}

The experimental design was a $3 \times 2$ factorial arrangement of treatments, which consisted of three maize cultivars differing in hardness (hard, semi-hard and soft) used in diets based on ground maize or $115 \mathrm{~g} / \mathrm{kg}$ whole maize replacing ground maize. A basal diet was formulated to meet or exceed Ross 308 strain recommendations for broiler starter chickens (Ross, 2007). The ingredient composition and calculated analysis of the basal diet is shown in Table 2. A portion of each maize cultivar was ground in a hammer mill to pass through a $4 \mathrm{~mm}$ sieve. Six experimental diets were then developed, composed of the three ground maize cultivars without or with substitution by whole maize. All diets contained titanium dioxide $(0.3 \%)$ as an indigestible dietary marker. Following mixing, the diets were cold pelleted $\left(65-70^{\circ} \mathrm{C}\right)$ with a pellet mill (Richard Size Limited Engineers, Orbit, Kingston-upon Hull, UK) equipped with a $3 \mathrm{~mm}$ die. Representative samples were collected after pelleting for determination of particle size distribution. 
Table 2. Composition and calculated analysis of the basal diet (as fed)

\begin{tabular}{lr}
\hline Ingredient & \% as-fed \\
\hline Maize $^{1}$ & 576.0 \\
Soybean meal & 359.9 \\
Vegetable oil & 18.5 \\
Dicalcium phosphate & 17.5 \\
Limestone & 15.7 \\
L-lysine & 0.2 \\
DL-methionine & 3.7 \\
Salt & 2.5 \\
Titanium dioxide & 3.0 \\
Trace Mineral premix & 2.5 \\
Vitamin premix & 0.5 \\
Calculated analysis & \\
AME, MJ/kg & 3010 \\
Crude protein, g/kg & 221 \\
Lysine, \% & 1.15 \\
Methionine + Cysteine, \% & 0.94 \\
Calcium & 1.09 \\
Total P & 0.71 \\
Non-phytate P & 0.45 \\
\hline
\end{tabular}

${ }^{1}$ Maize cultivars used were soft, semi-hard, and hard and were included in treatment diets either as $100 \%$ ground or $80 \%$ ground and $20 \%$ whole.

${ }^{2}$ Crude protein and gross energy of diets made from the three maize cultivars (hard, semi-hard and soft) analysed to contain 246, 240, $245 \mathrm{~g} / \mathrm{kg}$ and 18.5, 18.5 and 18.5 $\mathrm{MJ} / \mathrm{kg}$ respectively, on dry matter basis.

\section{General experimental procedure}

One-day-old male, Ross 208 broiler chicks (288 in total) were obtained from a commercial hatchery and assigned randomly to 36 cages (eight birds/cages) in three-tier batteries housed in an environmentally controlled room. Each cage was randomly assigned to one of the six dietary treatments (giving six replicates per treatment). Birds were transferred to colony cages in an environmentally controlled room on d 14 of age. Room temperature was maintained at $32 \pm 1^{\circ} \mathrm{C}$ during the first week and gradually reduced to $24^{\circ} \mathrm{C}$ by the end of the third week. Twenty hours of fluorescent lighting per day was provided. Diets were offered ad libitum and water was available throughout the 21-day trial. Body weight (BW) and feed intake were recorded on a cage basis at weekly intervals and mortality was recorded daily. Any bird that died was weighed, included in weekly weight gain data and used to adjust feed per gain.

\section{Determination of feed passage rate}

On day 15 , feed was withdrawn for $2 \mathrm{~h}$ and diets containing chromic oxide $(0.1 \%)$ were offered for $15 \mathrm{~min}$. The rate of passage was determined as the time from the introduction of the diets to the first appearance of greencoloured droppings.

\section{Apparent metabolisable energy determination}

Feed intake and excreta output for each cage were measured quantitatively for four days between day 17 to 21 . Total excreta from each cage were mixed thoroughly and two representative samples per cage were taken. Samples were freeze-dried, ground to pass through a $0.5 \mathrm{~mm}$ screen, and stored in airtight plastic containers at $4^{\circ} \mathrm{C}$ until analysis. Excreta and diet samples were analysed for dry matter (DM) and gross energy (GE).

\section{Apparent ileal digestibility of starch and nitrogen}

On day 21, two birds from each cage were euthanised using sodium pentobarbitone. The small intestine was immediately exposed and the contents of the lower half of the ileum were collected by gently flushing with distilled water into a plastic beaker. Digesta was pooled within a cage, lyophilised, ground to pass through a $0.5 \mathrm{~mm}$ screen, and stored in an airtight container at $4{ }^{\circ} \mathrm{C}$ until analysis. Digesta and diet samples were analysed for DM, titanium (Ti), nitrogen $(\mathrm{N})$ and starch.

\section{Digestive tract measurements}

On day 21, two birds (closest to the mean cage weight) were selected from each cage, body weights were recorded and birds were killed by cervical dislocation. The gastrointestinal tract and organs were carefully excised. Empty weights of the proventriculus and gizzard, and weights of pancreas, liver and spleen were recorded. Different segments of small intestine were emptied by gentle pressure and the empty weight and length of duodenum (pancreatic loop), jejunum (from the pancreatic loop to Meckel's diverticulum), ileum (from Meckel's diverticulum to ileo-caecal junction), and caeca (left and right) were recorded. Relative organ weights $(\mathrm{g} / \mathrm{kg} \mathrm{BW})$ and relative lengths $(\mathrm{cm} / \mathrm{kg} \mathrm{BW})$ were calculated.

\section{Digesta $\mathrm{pH}$ in different gastrointestinal segments}

On day 21, two additional birds per cage were killed by cervical dislocation and immediately eviscerated. A sample $(1 \mathrm{~g})$ of digesta from each segment of the gastrointestinal tract was removed. Contents were then mixed 1:10 with distilled water in a clean beaker and suspended by stirring manually with a glass rod for one minute after which $\mathrm{pH}$ was recorded using a digital $\mathrm{pH}$ meter (model IQ120, 2075-E Corte Del Nogal, Carlsbad, CA). 


\section{Chemical analysis}

Dry matter was determined using standard procedures (methods 930.15, 925.10; AOAC, 2005). Gross energy was determined by adiabatic bomb calorimetry (Gallenkamp Autobomb, London, UK) standardised with benzoic acid. The nitrogen content was determined by combustion (method 968.06; AOAC 2005) using a CNS-200 carbon, nitrogen, and sulphur auto analyser (LECO Corporation, St Joseph, MI). Titanium was determined by sulphuric acid digestion followed by colorimetric determination on a UV spectrophotometer as described by Short et al. (1996). Starch was measured using an assay kit (Megazyme, Bronia, VIC, Australia) based on conversion of starch to glucose using thermostable $\alpha$-amylase and amyloglucosidase (McCleary et al., 1997).

\section{Calculations}

The AME values were calculated using the following formula with appropriate corrections made for differences in DM content.

$\operatorname{AME}(\mathrm{MJ} / \mathrm{kg})$

$=\frac{\left(\text { Feed intake } \times \mathrm{GE}_{\text {diet }}\right)-\left(\text { Excreta output } \times \mathrm{GE}_{\text {excreta }}\right)}{\text { Feed intake }}$

Apparent ileal digestibility of starch and $\mathrm{N}$ was calculated as follows:

$$
\begin{aligned}
& \text { Ileal digestibility coefficient } \\
& =\frac{\left[(\text { Nutrient } / \text { Ti })_{\mathrm{d}}-(\text { Nutrient/Ti }) \mathrm{i}\right]}{(\text { Nutrient } / \text { Ti }) \mathrm{d}}
\end{aligned}
$$

Where, (Nutrient/Ti) diet is the ratio of nutrient $(\mathrm{N}$ or starch) to titanium in diet and (Nutrient/Ti) ileal is the ratio of nutrient ( $\mathrm{N}$ or starch) to titanium in ileal digesta

\section{Statistical analysis}

Cage means served as the experimental unit for statistical analysis. Data were subjected to two-way analysis of variance using the general linear model procedure of SAS (SAS Institute, 2004) to determine the main effects (maize hardness and whole maize inclusion) and their interaction. Differences were considered significant when $\mathrm{P}<0.05$.

\section{Results}

The particle size distribution of ground maize from the three cultivars and the six pelleted diets are presented in Figures 1 and 2, respectively. The grinding of maize cultivars varying in hardness, namely hard, semi-hard and soft, resulted in 16.6, 29.2 and $30.5 \%$ particles of $>1 \mathrm{~mm}$, respectively. The GMD of the ground hard, semi-hard and soft maize was determined to be $0.526 \mathrm{~mm}, 0.546 \mathrm{~mm}$ and $0.665 \mathrm{~mm}$.

The percentage of particles $>1 \mathrm{~mm}$ in diets pelleted with ground maize were 16.8, 18.0 and $21.3 \%$ for hard, semi-hard and soft maize, respectively. The corresponding values for diets containing whole maize were 18.9, 19.6 and $20.6 \%$, respectively. The GMD of pelleted diet without or with inclusion of whole hard, semi-hard and soft maize were similar, being $0.258,0.267,0.259$ or, $0.258,0.270$ and 0.266 , respectively.

The influence of dietary treatments on the performance of broilers is summarised in Table 3. No significant $(\mathrm{P}>0.05)$ interactions between whole maize inclusion and maize hardness were observed for weight gain, feed intake or feed per gain. However, weight gain showed a tendency $(\mathrm{P}=0.09)$ for interactions, whereby, with the inclusion of whole maize, weight gain decreased in birds fed the soft maize diet, increased in birds fed the semi-hard maize based diet, but was similar in birds fed the hard maize diet.

Whole maize inclusion had no effect $(\mathrm{P}>0.05)$ on the weight gain, feed intake and feed per gain of broilers. Maize hardness had no effect $(\mathrm{P}>0.05)$ on weight gain. Birds fed the hard maize based diet tended $(\mathrm{P}=0.08)$ to consume more feed than those fed on soft maize based diet. Feed per gain was significantly $(\mathrm{P}<0.05)$ influenced by maize hardness. Feed per gain of birds fed diets based on soft maize was lower $(\mathrm{P}<0.05)$ than those fed diets based on semi-hard maize, but was similar to those fed diets based on hard maize. No significant $(\mathrm{P}>0.05)$ difference was observed for feed per gain in birds fed diets based on hard and semi-hard maize.

Influence of maize hardness and whole maize inclusion on the AME, nitrogen and starch digestibility coefficients and digesta transit time in broilers is summarised in Table 4. No significant differences were observed for digesta transit time in birds fed the different treatment diets. Soft maize diets tended $(\mathrm{P}=0.06)$ to be retained for a longer time in the digestive tract compared to those based on hard and semi-hard maize.

Maize hardness and whole maize inclusion had no influence $(\mathrm{P}>0.05)$ on AME. However, a tendency $(\mathrm{P}=0.07)$ for interaction between whole maize inclusion and maize hardness was observed. With the inclusion of whole maize, AME was increased in broilers fed the hard 
Figure 1. Particle size distribution of maize; hard maize (HM), semi-hard (SHM) and soft (SM).

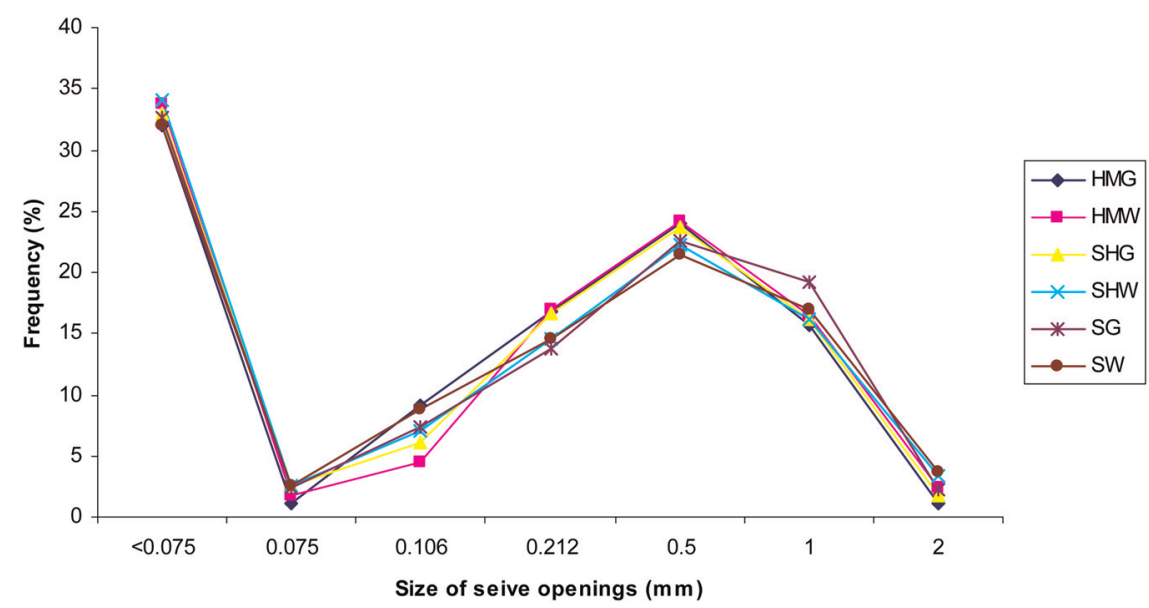

Figure 2. Particle size distribution of pelleted feeds; ground hard maize (HMG), whole hard maize (HMW), ground semi-hard maize (SHG), whole semi-hard maize (SHW), ground soft maize (SMG), whole soft maize (SMW).

maize based diet, decreased in birds fed the diet based on semi-hard maize and remained unchanged for the soft maize based diet.

Maize hardness influenced $(\mathrm{P}<0.05)$ the apparent ileal nitrogen digestibility. Nitrogen digestibility was higher $(\mathrm{P}<0.05)$ in broilers fed the diet based on soft maize compared to those fed diets based on hard and semi-hard maize. Nitrogen digestibility, however, was similar between broilers fed diets based on hard or semihard maize. Maize hardness tended $(\mathrm{P}=0.06)$ to influence ileal starch digestibility and the trends were similar to those observed for nitrogen digestibility. Whole maize inclusion had no influence $(\mathrm{P}>0.05)$ on the ileal nitrogen and starch digestibility and no interactions were observed.
Influence of whole maize inclusion and maize hardness on the relative weight of digestive organs in broilers is presented in Table 5. No significant $(\mathrm{P}>0.05)$ interaction between maize hardness and whole maize was observed for the relative weight of digestive organs, except for the proventriculus. With the inclusion of whole maize, the relative weight of proventriculus was reduced in birds fed the semi-hard maize diet, but unaffected in birds fed those based on hard or soft maize. Maize hardness and whole maize inclusion had no influence $(\mathrm{P}>0.05)$ on the relative weights of pancreas, liver, and spleen. However, the relative weight of gizzard was higher $(\mathrm{P}<0.05)$ in birds fed hard and semi-hard maize compared to soft maize, and higher $(\mathrm{P}<0.05)$ when whole maize replaced the ground maize in the diet. 
Table 3. Influence of maize hardness and whole maize inclusion on weight gain $(\mathrm{g} / \mathrm{bird})$, feed intake $(\mathrm{g} / \mathrm{bird})$, feed per gain $(\mathrm{g} / \mathrm{g})$ for broilers (1-21 days post hatch $)^{1}$

\begin{tabular}{|c|c|c|c|c|}
\hline Maize hardness & $\begin{array}{l}\text { Whole } \\
\text { maize }\end{array}$ & $\begin{array}{l}\text { Weight } \\
\text { gain }\end{array}$ & $\begin{array}{l}\text { Feed } \\
\text { intake }\end{array}$ & $\begin{array}{c}\text { Feed per } \\
\text { gain }\end{array}$ \\
\hline \multirow[t]{2}{*}{ Hard } & - & 988 & 1304 & 1.132 \\
\hline & + & 983 & 1289 & 1.312 \\
\hline \multirow[t]{2}{*}{ Semi-hard } & - & 959 & 1282 & 1.336 \\
\hline & + & 976 & 1285 & 1.328 \\
\hline \multirow[t]{2}{*}{ Soft } & - & 993 & 1271 & 1.301 \\
\hline & + & 952 & 1256 & 1.320 \\
\hline SEM $^{2}$ & & 12.8 & 14.13 & 0.008 \\
\hline \multicolumn{5}{|l|}{ Main effects } \\
\hline \multicolumn{5}{|l|}{ Maize hardness } \\
\hline Hard & & 986 & 1296 & $1.316^{\mathrm{ab}}$ \\
\hline Semi-hard & & 972 & 1284 & $1.332^{\mathrm{a}}$ \\
\hline Soft & & 968 & 1264 & $1.311^{b}$ \\
\hline \multicolumn{5}{|l|}{ Whole maize } \\
\hline- & & 980 & 1286 & 1.319 \\
\hline+ & & 970 & 1277 & 1.320 \\
\hline \multicolumn{5}{|l|}{$\begin{array}{l}\text { Probabilities, } \\
P \leq\end{array}$} \\
\hline Maize hardness & & NS & 0.08 & * \\
\hline Whole maize & & NS & NS & NS \\
\hline $\begin{array}{l}\text { Whole maize } \times \text { maize } \\
\text { hardness }\end{array}$ & & 0.09 & NS & NS \\
\hline
\end{tabular}

NS, not significant: ${ }^{*}, \mathrm{P}<0.05$.

a,b Means in column not sharing a common superscript are significantly different $(\mathrm{P}<0.05)$.

${ }^{1}$ Each value represents the mean of six replicates (eight birds per replicate).

${ }^{2}$ Pooled standard error of mean.

Neither any interaction nor any significant $(\mathrm{P}>0.05)$ main effects were observed on the relative weight and length of different segments of small intestine and caeca (Table 6). However, the relative weight of caeca tended $(\mathrm{P}=0.09)$ to be higher when whole maize was included in hard maize diets but showed no change in the semi-hard and soft diet.

A significant $(\mathrm{P}<0.01)$ interaction between maize hardness and whole maize inclusion was observed for the $\mathrm{pH}$ of digesta of the duodenum and jejunum (Table 7). With the inclusion of whole maize, an increase in $\mathrm{pH}$ of duodenal digesta was observed in birds fed hard maize while $\mathrm{pH}$ decreased in birds fed semi-hard and soft maize diets. With the inclusion of whole maize, $\mathrm{pH}$ of digesta of jejunum was not different between the birds fed semihard and soft maize, but higher in those fed diets based on hard maize. Maize hardness influenced $(\mathrm{P}<0.05)$ the $\mathrm{pH}$ of gizzard. Broilers fed soft maize diets had a lower $\mathrm{pH}$ as compared to those fed with either hard or semi- hard maize based diets.

\section{Discussion}

Particle size distribution and the GMD of three ground maize cultivars showed that the percentage of large particles $(>1 \mathrm{~mm})$ increased with decreasing hardness. This trend was unexpected and difficult to explain. This effect may be reflective of differences in the thickness of pericarp of the maize grain amongst the three cultivars; however, there is no evidence of difference in the thickness amongst these cultivars (Hardacre, A., Unpublished data). Another possible explanation may be that the brittleness of maize grain increases with increasing hardness and when pressure is applied in hammer mill for its grinding, harder maize, being more brittle, breaks into more smaller size particles.

It is noteworthy that the GMD of pelleted diets decreased with the inclusion of whole grain. This may be attributed to a milling effect and the pelleting process resulting changes in feed microstructure due to the grinding effect in the pellet press and frictional forces inside the die holes, an effect which has been shown to be particularly marked in diets containing coarser particles (Svihus et al. 2004b; Abdollahi et al. 2013).

The main aim of present study was to examine the effects of whole maize inclusion in broilers fed on maize-based diets. It was hypothesised that whole and/or hard maize would require greater grinding activity in the gizzard, stimulating the size of this organ, leading to better utilisation of feed and improved bird performance. In present study, birds fed diets containing whole maize had heavier gizzards, but weight gain, feed intake and feed per gain were similar to those birds fed diets containing ground maize. This observation is in agreement with the findings of Clark et al. (2009) who fed different levels of cracked maize to broilers at 0 to $680 \mathrm{~g} / \mathrm{kg}$ diet during three stages of growth from $0-42$ days of age and found that the inclusion of cracked maize up to $170 \mathrm{~g} / \mathrm{kg}$ of diet had no negative effects on performance parameters. In contrast, Singh et al. (2014a) reported graded inclusions of coarse maize in mash diets at 0 to $600 \mathrm{~g} / \mathrm{kg}$ diet resulted in a linear increase in weight gain and feed intake of broilers, with no effect on feed per gain. In another study, Singh et al. (2014b) used pre-pelleting inclusion of similar graded levels of whole maize and failed to show any beneficial effect on the weight gain of broilers.

Studies investigating use of whole grains other than wheat are limited. Published data on the effect of whole wheat feeding on the performance of broilers have been contradictory, with some reports showing beneficial effects (Wu et al., 2004; Ravindran et al., 2006), while others failed to show any advantage (Bennett et al., 2002; Amerah and Ravindran 2008). Moss et al. (2018) fed broilers diets with different 
Whole maize and endosperm hardness

Table 4. Influence of maize hardness and whole maize inclusion on the AME (MJ/kg DM), nitrogen and starch digestibility coefficient and digesta transit time for broilers starter (1-21 days post hatch) ${ }^{1}$

\begin{tabular}{|c|c|c|c|c|c|}
\hline Maize hardness & Whole maize & AME & $\begin{array}{c}\text { Nitrogen } \\
\text { digestibility }\end{array}$ & $\begin{array}{c}\text { Starch } \\
\text { digestibility }\end{array}$ & Transit time (min) \\
\hline \multirow[t]{2}{*}{ Hard } & - & 14.34 & 0.852 & 0.973 & 139 \\
\hline & + & 14.41 & 0.831 & 0.981 & 139 \\
\hline \multirow[t]{2}{*}{ Semi-hard } & - & 14.63 & 0.838 & 0.971 & 136 \\
\hline & + & 14.27 & 0.846 & 0.970 & 134 \\
\hline \multirow[t]{2}{*}{ Soft } & - & 14.35 & 0.863 & 0.977 & 140 \\
\hline & + & 14.36 & 0.861 & 0.984 & 143 \\
\hline \multicolumn{2}{|l|}{$\mathrm{SEM}^{2}$} & 0.059 & 0.008 & 0.004 & 3.31 \\
\hline \multicolumn{6}{|l|}{ Main effects } \\
\hline \multicolumn{6}{|l|}{ Maize hardness } \\
\hline \multicolumn{2}{|l|}{ Hard } & 14.37 & $0.842^{b}$ & 0.977 & 134 \\
\hline \multicolumn{2}{|l|}{ Semi-hard } & 14.36 & $0.842^{\mathrm{b}}$ & 0.970 & 135 \\
\hline \multirow{2}{*}{\multicolumn{2}{|c|}{$\begin{array}{l}\text { Soft } \\
\text { Whole maize }\end{array}$}} & 14.36 & $0.862^{\mathrm{a}}$ & 0.981 & 141 \\
\hline & & & & & \\
\hline \multicolumn{2}{|l|}{+} & 14.38 & 0.851 & 0.974 & 138 \\
\hline \multirow{2}{*}{\multicolumn{2}{|c|}{$\begin{array}{l}- \\
\text { Probabilities, } \mathrm{P} \leq\end{array}$}} & 14.35 & 0.846 & 0.978 & 135 \\
\hline & & & & & \\
\hline \multicolumn{2}{|l|}{ Maize hardness } & NS & * & 0.06 & 0.06 \\
\hline \multicolumn{2}{|c|}{ Whole maize } & NS & NS & NS & NS \\
\hline \multicolumn{2}{|c|}{ Whole maize $\times$ maize hardness } & 0.07 & NS & NS & NS \\
\hline
\end{tabular}

NS, not significant: ${ }^{*}, \mathrm{P}<0.05$.

a,b Means in column not sharing a common superscript are significantly different $(P<0.05)$

1 Each value represents the mean of six replicates (8 birds per replicate).

${ }^{2}$ Pooled standard error of mean.

Table 5. Relative weight ( $\mathrm{g} / \mathrm{kg} \mathrm{BW}$ ) of organs (proventriculus, gizzard, pancreas, liver and spleen) of broilers ${ }^{1}$ at 21 days of age as influenced by whole maize inclusion and maize hardness

\begin{tabular}{|c|c|c|c|c|c|c|}
\hline \multicolumn{7}{|l|}{ Treatment } \\
\hline Maize hardness & Whole maize & Proventriculus & Gizzard & Pancreas & Liver & Spleen \\
\hline \multirow[t]{2}{*}{ Hard } & - & $4.04^{\mathrm{ab}}$ & 14.5 & 2.54 & 26.6 & 0.791 \\
\hline & + & $4.02^{\mathrm{ab}}$ & 16.0 & 2.57 & 27.3 & 0.733 \\
\hline \multirow[t]{2}{*}{ Semi-hard } & - & $4.18^{\mathrm{a}}$ & 15.1 & 2.80 & 26.1 & 0.741 \\
\hline & + & $3.75^{\mathrm{b}}$ & 15.8 & 2.65 & 27.2 & 0.800 \\
\hline \multirow[t]{2}{*}{ Soft } & - & $3.97^{\mathrm{ab}}$ & 13.5 & 2.60 & 26.4 & 0.758 \\
\hline & + & $4.26^{\mathrm{a}}$ & 14.3 & 2.42 & 26.9 & 0.750 \\
\hline \multicolumn{2}{|l|}{$\mathrm{SEM}^{2}$} & 0.139 & 0.51 & 0.140 & 0.68 & 0.045 \\
\hline \multicolumn{7}{|l|}{ Main effects } \\
\hline \multicolumn{7}{|l|}{ Maize hardness } \\
\hline \multicolumn{2}{|l|}{ Hard } & 4.03 & $15.3^{\mathrm{a}}$ & 2.55 & 27.0 & 0.762 \\
\hline \multicolumn{2}{|l|}{ Semi-hard } & 3.97 & $15.4^{\mathrm{a}}$ & 2.72 & 26.7 & 0.770 \\
\hline \multicolumn{2}{|l|}{$\begin{array}{l}\text { Soft } \\
\text { Whole maize }\end{array}$} & 4.12 & $13.9^{\mathrm{b}}$ & 2.51 & 26.7 & 0.754 \\
\hline \multicolumn{7}{|l|}{ Whole maize } \\
\hline \multicolumn{2}{|l|}{-} & 4.01 & $14.4^{\mathrm{b}}$ & 2.65 & 26.4 & 0.763 \\
\hline \multirow{2}{*}{\multicolumn{2}{|c|}{$\stackrel{+}{\text { Probabilities, } \mathrm{P} \leq}$}} & 4.06 & $15.4^{\mathrm{a}}$ & 2.55 & 27.2 & 0.761 \\
\hline & & & & & & \\
\hline \multicolumn{2}{|l|}{ Maize hardness } & NS & * & NS & NS & NS \\
\hline \multicolumn{2}{|c|}{ Whole maize } & NS & * & NS & NS & NS \\
\hline \multicolumn{2}{|c|}{ Whole maize $\times$ maize hardness } & * & NS & NS & NS & NS \\
\hline
\end{tabular}

NS, not significant: ${ }^{*}, \mathrm{P}<0.05$

a,b Means in column not sharing a common superscript are significantly different $(P<0.05)$.

${ }^{1}$ Each value represents the mean of 6 replicates.

2 Pooled standard error of mean.

inclusion levels of whole wheat at $0,75,150$ and $300 \mathrm{~g} / \mathrm{kg}$ and reported that pre-pelleting inclusion of whole wheat had no influence on weight gain but post-pellet blended rations linearly decreased weight gain. Taylor and Jones (2001) reported that pre-pelleting inclusion of whole wheat at $200 \mathrm{~g} / \mathrm{kg}$ resulted in heavier gizzard weights, 
Table 6. Relative weight ( $\mathrm{g} / \mathrm{kg} \mathrm{BW}$ ) and length ( $\mathrm{cm} / \mathrm{kg} \mathrm{BW}$ ) of the intestinal tract of male broilers ${ }^{1}$ at 21 days of age as influenced by whole maize inclusion and maize hardness

\begin{tabular}{|c|c|c|c|c|c|c|c|c|c|c|c|}
\hline \multicolumn{2}{|l|}{ Treatment } & \multicolumn{2}{|c|}{ Duodenum } & \multicolumn{2}{|c|}{ Jejunum } & \multicolumn{2}{|c|}{ Ileum } & \multicolumn{2}{|c|}{ Caeca } & \multirow{2}{*}{$\begin{array}{c}\text { SI } \\
\text { g/kg BW }\end{array}$} & \multirow{2}{*}{$\begin{array}{c}\mathrm{SI} \\
\mathrm{cm} / \mathrm{kg} \\
\mathrm{BW}\end{array}$} \\
\hline Maize hardness & Whole maize & $\mathrm{g} / \mathrm{kg} \mathrm{BW}$ & $\begin{array}{c}\mathrm{cm} / \mathrm{kg} \\
\mathrm{BW}\end{array}$ & $\mathrm{g} / \mathrm{kg} \mathrm{BW}$ & $\begin{array}{c}\mathrm{cm} / \mathrm{kg} \\
\mathrm{BW}\end{array}$ & $\mathrm{g} / \mathrm{kg} \mathrm{BW}$ & $\begin{array}{c}\mathrm{cm} / \mathrm{kg} \\
\mathrm{BW}\end{array}$ & $\mathrm{g} / \mathrm{kg} \mathrm{BW}$ & $\begin{array}{c}\mathrm{cm} / \mathrm{kg} \\
\mathrm{BW}\end{array}$ & & \\
\hline \multirow[t]{2}{*}{ Hard } & - & 5.89 & 26.5 & 10.5 & 65.8 & 7.84 & 68.3 & 1.53 & 13.9 & 24.2 & 22.7 \\
\hline & + & 6.17 & 27.6 & 10.7 & 63.5 & 7.65 & 67.1 & 1.76 & 14.3 & 24.5 & 23.4 \\
\hline \multirow[t]{2}{*}{ Semi-hard } & - & 5.85 & 27.3 & 11.2 & 65.6 & 8.14 & 70.7 & 1.61 & 14.0 & 25.2 & 24.7 \\
\hline & + & 5.61 & 26.3 & 10.3 & 63.8 & 7.25 & 64.5 & 1.60 & 14.1 & 23.2 & 21.8 \\
\hline \multirow[t]{2}{*}{ Soft } & - & 5.87 & 26.6 & 11.3 & 65.4 & 7.85 & 68.4 & 1.65 & 13.9 & 25.0 & 23.9 \\
\hline & + & 5.75 & 28.1 & 10.1 & 65.9 & 7.63 & 69.5 & 1.60 & 14.3 & 23.5 & 23.9 \\
\hline SEM $^{2}$ & & 0.265 & 0.79 & 0.53 & 1.84 & 0.301 & 1.92 & 0.068 & 0.42 & 0.91 & 0.99 \\
\hline \multicolumn{12}{|c|}{ Main effects means } \\
\hline \multicolumn{12}{|c|}{ Maize hardness } \\
\hline Hard & & 6.03 & 27.0 & 10.6 & 64.6 & 7.74 & 67.7 & 1.65 & 14.1 & 24.4 & 23.9 \\
\hline Semi-hard & & 5.73 & 26.8 & 10.7 & 64.7 & 7.70 & 67.6 & 1.61 & 14.1 & 24.2 & 23.3 \\
\hline Soft & & 5.81 & 27.3 & 10.7 & 65.7 & 7.74 & 68.9 & 1.62 & 14.1 & 24.3 & 23.1 \\
\hline \multicolumn{12}{|l|}{ Whole maize } \\
\hline- & & 5.87 & 26.8 & 11.0 & 65.6 & 7.94 & 69.1 & 1.60 & 13.9 & 23.7 & 23.8 \\
\hline+ & & 5.85 & 27.3 & 10.4 & 64.4 & 7.51 & 67.0 & 1.65 & 14.2 & 24.8 & 23.0 \\
\hline \multicolumn{12}{|l|}{ Probabilities, $\mathrm{P} \leq$} \\
\hline Maize hardness & & NS & NS & NS & NS & NS & NS & NS & NS & NS & NS \\
\hline Whole maize & & NS & NS & NS & NS & 0.08 & NS & NS & NS & NS & NS \\
\hline Whole maize $\times n$ & hardness & NS & NS & NS & NS & NS & NS & 0.09 & NS & NS & NS \\
\hline
\end{tabular}

NS, not significant: * $\mathrm{P}<0.05$.

a,b Means in column not sharing a common superscript are significantly different $(\mathrm{P}<0.05)$.

${ }^{1}$ Each value represents the mean of 6 replicates.

${ }^{2}$ Pooled standard error of mean.

Table 7. $\mathrm{pH}$ of digesta in different parts of digestive tract in broilers ${ }^{1}$ at 21 days of age as Influenced by whole maize inclusion and maize hardness

\begin{tabular}{|c|c|c|c|c|c|c|}
\hline \multicolumn{2}{|l|}{ Treatment } & \multirow[b]{2}{*}{ Gizzard } & \multirow[b]{2}{*}{ Proventriculus } & \multirow[b]{2}{*}{ Duodenum } & \multirow[b]{2}{*}{ Jejunum } & \multirow[b]{2}{*}{ Ileum } \\
\hline Maize hardness & Whole maize & & & & & \\
\hline \multirow[t]{2}{*}{ Hard } & - & 3.75 & 3.90 & $6.25^{\mathrm{b}}$ & $6.25^{c}$ & 7.35 \\
\hline & + & 3.50 & 4.45 & $6.65^{a}$ & $6.80^{\mathrm{a}}$ & 7.40 \\
\hline \multirow[t]{2}{*}{ Semi-hard } & - & 3.77 & 3.85 & $6.65^{\mathrm{a}}$ & $6.65^{\mathrm{ab}}$ & 7.45 \\
\hline & + & 3.69 & 3.55 & $6.30^{\mathrm{b}}$ & $6.40^{\mathrm{bc}}$ & 7.35 \\
\hline \multirow[t]{2}{*}{ Soft } & - & 3.42 & 2.05 & $6.60^{\mathrm{a}}$ & $6.70^{\mathrm{ab}}$ & 7.60 \\
\hline & + & 3.45 & 3.3 & $6.40^{\mathrm{b}}$ & $6.65^{\mathrm{ab}}$ & 7.75 \\
\hline SEM $^{2}$ & & 0.087 & 0.802 & 0.05 & 0.097 & 0.168 \\
\hline \multicolumn{7}{|l|}{ Main effects } \\
\hline \multicolumn{7}{|l|}{ Maize hardness } \\
\hline Hard & & $3.63^{a}$ & 4.17 & 6.45 & 6.52 & 7.37 \\
\hline Semi-hard & & $3.73^{\mathrm{a}}$ & 3.70 & 6.47 & 6.52 & 7.40 \\
\hline Soft & & $3.44^{\mathrm{b}}$ & 2.65 & 6.50 & 6.67 & 7.67 \\
\hline \multicolumn{7}{|l|}{ Whole maize } \\
\hline- & & 3.65 & 3.26 & 6.50 & 6.53 & 7.46 \\
\hline+ & & 3.55 & 3.76 & 6.45 & 6.61 & 7.50 \\
\hline \multicolumn{7}{|l|}{ Probabilities, $\mathrm{P} \leq$} \\
\hline Maize hardness & & * & NS & NS & NS & NS \\
\hline Whole maize & & NS & NS & NS & NS & NS \\
\hline \multicolumn{2}{|c|}{ Whole maize $\times$ maize hardness } & NS & NS & $\star \star \star$ & $\star *$ & NS \\
\hline
\end{tabular}

NS, not significant: ${ }^{*}, \mathrm{P}<0.05 .{ }^{* *}, \mathrm{P}<0.01{ }^{* \star *}, \mathrm{P}<0.001$.

a,b Means in column not sharing a common superscript are significantly different $(P<0.05)$.

${ }^{1}$ Each value represents the mean of 4 observations.

2 Pooled standard error of mean.

but had no effect on weight gain and feed efficiency. In contrast, Wu et al. (2004) with pre-pelleting inclusion of whole wheat at $200 \mathrm{~g} / \mathrm{kg}$ failed to show any effect on gizzard weight but observed improved weight gain and feed efficiency.
In the present study, whole maize inclusion, regardless of its hardness, had no effect on AME. Uddin et al. (1996), compared two wheat cultivars selected to be similar in nutrient composition but differing in endosperm hardness and found no effect either in ground or in 
whole grain form and wheat hardness on the AME, growth or feed per gain of broilers. Similarly, Amerah et al. (2009) found no effect of wheat hardness on broiler performance or AME. Singh et al. (2014a) reported that the AME was not influenced up to $300 \mathrm{~g} / \mathrm{kg}$ inclusion of coarse maize and then decreased with further inclusions. Previous studies with whole wheat inclusion at levels of 100 to $375 \mathrm{~g} / \mathrm{kg}$ gave improvements in AME (Preston et al., 2000; Svihus et al., 2004a; Wu et al., 2004). However, higher inclusion levels of 400 to $500 \mathrm{~g} / \mathrm{kg}$ failed to show any effect on AME (Svihus et al., 2004a).

In the current trial, whole maize feeding had no influence on the ileal nitrogen and starch digestibility, in agreement with the findings of Singh et al. (2014b). In contrast, several previous studies with whole grain have reported improvements in the ileal and starch digestibility (Svihus et al., 2004a; Wu et al., 2004; Singh et al., 2015). Interestingly, in the present study, ileal nitrogen and starch digestibility improved in broilers fed the soft maize based diet, but no effect was seen for those fed hard or semi-hard maize based diets. It must be noted that gizzard weight was unaffected in soft maize fed birds. In the study of Wu et al (2004), pre-pelleted whole wheat generated substantial increases in nutrient digestibility without tangibly increasing gizzard weight. From the tested hypothesis of the present study, whole and hard maize cultivars increased gizzard weight, which was consistent with the results from previous whole grain studies (Svihus et al., 2004a; Singh et al., 2014a; Singh et al., 2015; Moss et al., 2018). Amerah et al. (2009) reported that feeding hard wheat cultivars resulted in relatively heavier gizzard weight in comparison to soft wheat.

No plausible explanation can be given for the decrease in the weight of proventriculus with inclusion of whole maize from semi-hard cultivar fed birds. No effects of whole maize and hardness were observed on the weight and length of various segments of digestive tract. This is inconsistent with the result of previous studies (Wu et al., 2004; Ravindran et al., 2006). In contrast, Amerah et al. (2009) reported that the relative weight of gut components was lower in birds fed soft wheat than those maintained on hard wheat-based diets. Whole maize had no effect on the digesta transit time, consistent with previous studies (Svihus et al., 2002; Wu et al., 2004; Amerah and Ravindran, 2008; Singh et al., 2014a).

Whole maize had no effect on the $\mathrm{pH}$ of gizzard digesta, which is in agreement with the findings of
Singh et al. (2014a). Hetland et al. (2002) reported that the cereal species or the form of cereals did not conclusively affect the $\mathrm{pH}$ of gizzard contents. However, significant decreases in the $\mathrm{pH}$ of gizzard content have been reported in some studies with the inclusion of whole wheat (Nir et al., 1994; Gabriel et al., 2003) and maize (Singh et al., 2014b).

\section{Conclusions}

Overall, the present data showed that $115 \mathrm{~g} / \mathrm{kg}$ replacement of ground maize with whole maize has no adverse effects on the growth parameters, AME or ileal nutrient digestibility in young broilers and therefore this strategy could potentially be used to reduce the cost of manufacturing broiler feeds.

\section{Acknowledgments}

The authors would like to thank Allan Hardacre, Institute of Food Nutrition and Human Health, Massey University, Palmerston North for his support.

\section{Declaration of Interest}

None.

\section{References}

AOAC. (2005) Official Methods of Analysis, 18th edition. AOAC International, Washington DC.

Abdollahi M.R., Ravindran V. and Svihus B. (2013) Pelleting of broiler diets: an overview with emphasis on pellet quality and nutritional value. Animal Feed Science and Technology, 179: 1-23.

Amerah A.M., Ravindran V. and Lentle R.G. (2009) Influence of wheat hardness and xylanase supplementation on the performance, energy utilization, digestive tract development and digesta parameters of broiler starters. Animal Production Science, 49: 71-78.

Amerah A.M. and Ravindran V. (2008) Influence of method of whole wheat feeding on the Performance, digestive tract development and carcass traits of broiler chickens. Animal Feed Science and Technology, 147: 326-339.

Baker S. and Herrman T. (2002) Evaluating particle size. MF-2051 Feed manufacturing, Department of Grain science and industry, Kansa State University, Manhattan, KS.

Bennett C.D., Classen H.L. and Riddell C. (2002) Broiler chickens wheat and barley diets containing whole, ground and pelleted grain. Poultry Science, 81: 995-1003.

Clark P.M., Behnke K.C. and Fahrenholz A.C. (2009) Effect of feeding cracked corn and concentrate protein pellets on broiler performance. Journal of Applied Poultry Research, 18: 259-268.

Gabriel I., Mallet S. and Leconte M. (2003) Differences in the digestive tract characteristics of broiler chickens fed on complete pelleted diet or on whole wheat added to pelleted protein concentrate. British Poultry Science, 44: 283-290.

Gabriel I., Mallet S., Laconte M., Tavel A. and Lalles J.P. (2007) Effect of whole wheat feeding on the development of the digestive tract of broiler chickens. Animal Feed Science and Technology, 142: 144-162. 
Hetland H., Svihus B. and Olaisen V. (2002) Effect of feeding whole cereals on performance, starch digestibility and duodenal particle size distribution in broiler chickens. British Poultry Science, 43: 416-423.

Lentle R.G., Ravindran V., Ravindran G. and Thomas D.V. (2006) Influence of feed particle size on the efficiency of broiler chickens fed wheat-based diets. Journal of Poultry Science, 43: 135-142.

Liu S.Y., Truong H.H. and Selle P.H. (2015) Whole-grain feeding for meat-chicken production: possible mechanisms driving enhanced energy utilisation and feed conversion. Animal Production Science, 55: 559-572.

Mccleary B.V., Gibson T.S. and Mugford D.C. (1997) Measurement of total Starch in cereals products by amyloglucosidase vs. amylase method: collaborative study. Journal of the Association of Official Analytical Chemists, 80: 571-579.

Moss A. F., Truong H.H., Liu S.Y. and Selle P.H. (2018) Inclusion levels and modes of whole grain incorporation into wheat-based rations differentially influence the performance of broiler chickens. British Poultry Science, 59: 110-120.

Nir I., Hillel R., Shefet G. and Nitsan Z. (1994) Effect of grain particle size on performance. 2. Grain texture interactions. Poultry Science, 73: 781-791.

Pomeranz Y., Czuchajowska Z., Martin C.R., and Lai F.S. (1985) Determination of corn hardness by the Stenvert hardness tester. Cereal Chemistry, 62:108-112.

Preston C.M., McCracken K.J. and McAllister A. (2000) Effect of diet form and enzyme supplementation on growth, efficiency and energy utilisation of wheat-based diets for broilers. British Poultry Science, 41: 324-331.

Ravindran V., Wu Y.B., Thomas D.G. and Morel P.C.H. (2006) Influence of whole wheat feeding on the development of digestive organs and performance of broiler chickens. Australian Journal of Agricultural Research, 57: 21-16.

Rodriques I. and Choct M. (2018) The foregut and its manipulation via feeding practices in the chicken. Poultry Science, 97: 3188-3206.

Ross. (2007) Ross 308 Broiler: Nutrition Specification, Ross Breeders Limited, Newbridge, Midlothian, Scotland, UK

SAS. (2004) SAS/STAT ${ }^{\circledR}$ User's Guide: Statistics, Version 6.12. SAS Institute Inc., Cary, NC.

Short F.J., Gorton P., Wiseman J. and Boorman K.N. (1996) Determination of titanium dioxide added as an inert marker in chicken digestibility studies. Animal Feed Science and Technology, 59: 215-221.
Singh Y., Ravindran V. and Molan A.L. (2015) Influence of whole wheat feeding on the development of coccidiosis in broilers challenged with Eimeria. Research in Veterinary Science, 100: 125-130.

Singh Y., Ravindran V., Wester T.J., Molan A.L. and Ravindran G. (2014a) Influence of feeding coarse corn on performance, nutrient utilization, digestive tract measurements, carcass characteristics and cecal microflora counts of broilers. Poultry Science, 93: 606-616

Singh Y., Ravindran V., Wester T.J., Molan A.L. and Ravindran G. (2014b) Influence of pre-pelleting inclusion of whole corn on performance, nutrient utilization, digestive tract measurements, and cecal microbiota of young broilers. Poultry Science, 93: 3073-3082.

Stenvert N.L. (1974) Grinding resistance, a simple measure of wheat hardness. Flour and Animal Feed Milling, 12:24-27.

Svihus B., Hetland H., Choct M. and Sundby F. (2002) Passage rate through the anterior digestive tract of broiler chickens fed on diets with ground and whole wheat. British Poultry Science, 43: 662-668

Svihus B., Juvik E., Hetland H. and Krogdahl Å. (2004a). Causes for improvement in nutritive value of broiler chicken diets with whole wheat instead of ground wheat. British Poultry Science, 45: 55-60.

Svihus B., Kløvstad K.H., Perez V., Zimonja O., Sahlström S., Schüller R.B., Jeksrud W.K. and Prestløkken E. (2004b) Physical and nutritional effects of pelleting of broiler chicken diets made from wheat ground to different coarseness by the use of roller mill and hammer mill. Animal Feed Science and Technology, 117: 281-293.

Taylor R.D. and Jones G.P.D. (2001) The effect of whole wheat, ground wheat and dietary enzymes on performance and gastrointestinal morphology of boilers. Proceedings of the 13th Australian Poultry Science Symposium, Australia, pp. 187-190.

Uddin M.S., Rose S.P., Hiscock T.A. and Bonnet S. (1996) A comparison of the energy availability for chickens of ground and whole grain samples of two wheat varieties. British Poultry Science, 37: 347-357.

Wu Y.B., Ravindran V., Thomas G.D., Birtles M.J. and Hendricks W.H. (2004) Influence of method of whole wheat inclusion and xylanase supplementation on the performance, apparent metabolisable energy, digestive tract measurements and gut morphology of broilers. British Poultry Science, 45: 385-394. 